\title{
Technologies for Jatoba Seedling Formation
}

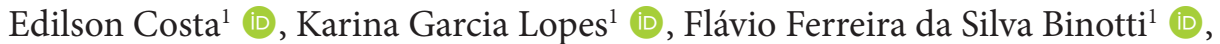 \\ Eliana Duarte Cardoso Binotti ${ }^{1}$ iD, Cleiton Dalastra ${ }^{1}$
}

${ }^{1}$ Unidade Universitária de Cassilândia, Universidade Estadual de Mato Grosso do Sul - UEMS, Cassilândia/MS, Brasil.

\begin{abstract}
This research evaluated protected environment and substrates for jatoba seedling. Two protected environments were used: (i) black shading screen on the sides and roof; and, (ii) black shading screen on the sides and thermal-reflective aluminized screen on the roof. In each environment the following substrates formulated with cattle manure $(\mathrm{M})$ and vermiculite $(\mathrm{V})$ were tested: $100 \% \mathrm{M} ; 90 \% \mathrm{M}+10 \% \mathrm{~V} ; 80 \% \mathrm{M}+20 \% \mathrm{~V} ; 70 \% \mathrm{M}+30 \% \mathrm{~V} ; 60 \% \mathrm{M}+40 \% \mathrm{~V} ; 50 \% \mathrm{M}+50 \% \mathrm{~V}$; $40 \% \mathrm{M}+60 \% \mathrm{~V} ; 30 \% \mathrm{M}+70 \% \mathrm{~V} ; 20 \% \mathrm{M}+80 \% \mathrm{~V} ; 10 \% \mathrm{M}+90 \% \mathrm{~V}$. The environment protected with black shading screen was more favorable for the formation of jatoba seedlings, resulting in seedlings with higher shoot height and root collar diameter and, therefore, higher quality. Recommendation is to use substrates containing up to $30 \%$ of cattle manure to produce high quality jatoba seedlings.
\end{abstract}

Keywords: Hymenaea courbaril, substrates, protected environments. 


\section{INTRODUCTION AND OBJECTIVES}

The jatoba [Hymenaea courbaril L. var. stilbocarpa (Hayne) Lee et Lang.; Fabaceae - Caesalpinioideae] commonly known in Brazil as "jatobá-da-mata" or "jatobá-verdadeiro", is a tree native to Latin America and widely distributed in Gallery forests of the Cerrado biome (Mazzei et al., 1999). This species has been widely used in reforestation of degraded areas and mixed plantations, mainly for its fast-initial growth and rusticity. In addition, this rapid initial growth rate is an efficient mechanism for carbon sequestration in forests (Aidar et al., 2002). The planting of the jatoba tree mixed with perennial species represents a crucial tool for forest deployment and management because the species is not affected by the management of fertilizers and green forage (Gandini et al., 2011).

According to Lima et al. (2010), it is a shade tolerant climax species, and according to Oliveira et al. (2011) it has regenerative and recruitment abilities in naturally shaded environments; however, its growth is limited under conditions of low light intensities. Campos \& Uchida (2002) reported that the cultivation of Hymenaea courbaril in an environment with $70 \%$ shading impaired seedling growth, contrary to the results observed by Mazzei et al. (1999). Campos \& Uchida (2002) highlight that the choice of shading is related to the parameters that indicate balanced growth as a whole and adequate root development. Mazzei et al. (1999) studied the initial growth of jatoba seedlings in full sun, and in environments with $50 \%$, $70 \%$ and $90 \%$ shading, and verified that the species can be used in the recovery of Gallery forests, since it has developed properly under full sun conditions and up to $70 \%$ shading.

Carvalho et al. (2003) evaluating different substrates for the jatoba seedling production under full sun conditions and in protected environment with 50\% shading screen, reported that the jatoba seedlings can be grown in a mixture of soil: sand: cattle manure (1: $2: 1)$, and in full sun conditions.

Pierezan et al. (2012) evaluating the emergence and early growth of jatoba seedlings with the application of biostimulant (Stimulate) under full sun conditions and in protected environment with $30 \%$ and $50 \%$ shading screen, observed that the biostimulant inhibited seed germination and initial seedling growth.
According to Lorenzi (2000), the time of seedling production is relatively quick, although the plant development in the field, in general, is slow and depends on the edaphoclimatic conditions. However, the survival rate of seedlings in the field is high. Indeed, Sano \& Fonseca (2003) verified the high survival rates of the jatoba plants in soil conditions of the Cerrado region, indicating the great success for the planting of jatoba in the reforestation of degraded areas and mixed plantations of the Cerrado.

This work aimed to study the effects of black shading screen and thermal-reflective aluminized screen, and different substrates combinations to produce jatoba seedlings [Hymenaea courbaril L. var. stilbocarpa (Hayne)] Lee et Lang.] under protected environment conditions.

\section{MATERIAL AND METHODS}

The experiment was carried out under protected environment conditions at the State University of Mato Grosso do Sul (UEMS), in Cassilândia, MS, Brazil

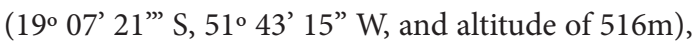
from November 2012 to February 2013.

Seeds of Hymenaea courbaril L. var. stilbocarpa ("jatoba") were extracted from mature fruits collected from trees established in a Cerrado area located in the Eastern region of Mato Grosso do Sul, in the municipality of Cassilândia, MS, Brazil. Seeds were previously selected considering its size and then submitted to priming by direct immersion in water for 24 hours. After priming period, seeds were put to dry in the shade at room temperature, and then the seed coat was sanded with a sandpaper No 40 on an area opposite to the embryo, as recommended by Costa et al. (2011).

After mechanical scarification, the seeds were immediately sown in 1.8 -L polyethylene bags $(15.0 \times 25.0 \mathrm{~cm})$ on November $18^{\text {th }}$, 2012, containing the different substrate combinations formulated with cattle manure $(\mathrm{M})$ and vermiculite $(\mathrm{V})$ as follows: $\mathrm{S} 1=100 \% \mathrm{M}$; S2 $=90 \%$ $\mathrm{M}+10 \% \mathrm{~V} ; \mathrm{S} 3=80 \% \mathrm{M}+20 \% \mathrm{~V} ; \mathrm{S} 4=70 \% \mathrm{M}+30 \%$ $\mathrm{V} ; \mathrm{S} 5=60 \% \mathrm{M}+40 \% \mathrm{~V} ; \mathrm{S} 6=50 \% \mathrm{M}+50 \% \mathrm{~V}$; $\mathrm{S} 7=40 \% \mathrm{M}+60 \% \mathrm{~V} ; \mathrm{S} 8=30 \% \mathrm{M}+70 \% \mathrm{~V} ; \mathrm{S} 9=20 \%$ $M+80 \% \mathrm{~V} ; \mathrm{S} 10=10 \% \mathrm{M}+90 \% \mathrm{~V}$. Two jatoba seeds were sown per container at a depth of $2-3 \mathrm{~cm}$, and 
after the establishment, they were thinned to one plant per container.

After sowing, the plastic bags were taken to two production environments and maintained under these conditions for a period of 65 days. Both protected environments used for the production of jatoba seedlings were: (i) agricultural shading screenhouse with galvanized steel structure, measuring $8.00 \mathrm{~m}$ width by $18.00 \mathrm{~m}$ length and $3.50 \mathrm{~m}$ high, closing at 45 degrees, with black shading screen on the sides and roof providing $50 \%$ of shade (A1); (ii) agricultural shading screenhouse with galvanized steel structure, measuring $8.00 \mathrm{~m}$ width by $18.00 \mathrm{~m}$ length and $4.00 \mathrm{~m}$ high, closing at 90 degrees, with black shading screen on the sides and thermal-reflective aluminized screen on the roof, both providing $50 \%$ of shade (A2).

Since there were no replicates for the protected environments, each one was considered an individual experiment. In each seedling production environment, the ten different substrate compositions were arranged in a completely randomized design with five replicates of the six seedlings each.

When the ratio between the mean square of the experimental error of two individual experiments (i.e., protected environments) was less than 7.0, it indicates that there is homogeneity between the residual mean squares variances (Banzatto \& Kronka, 2013); therefore, as the null hypothesis was accepted, the experiments can be grouped to analyze the existence of interaction between substrate types versus production environments. Thus, the mean of production environments was compared by the joint analysis of data from two experiments (Banzatto \& Kronka, 2013).

Before use, the fresh cattle manure was subjected to aerobic composting for 30 days. The composted material was then dried, homogenized, and sifted through a 3.70-mm mesh. The chemical characteristics of cattle manure were: $\mathrm{N}, \mathrm{P}, \mathrm{K}, \mathrm{Ca}, \mathrm{Mg}, \mathrm{S}, \mathrm{C}$, organic matter, in $\mathrm{kg}^{-1}, 18.4,1.71,1,15.05,0.7,1.95,141,244$, respectively; $\mathrm{pH}$ in water $=5.4$; moisture $=38.91 \%$; carbon and nitrogen ratio $=7.66$; and $\mathrm{Cu}, \mathrm{Zn}, \mathrm{Fe}, \mathrm{Mn}$, B, in $\mathrm{mg} \mathrm{kg}^{-1}, 18.5,125,6830,214,14$, respectively. The vermiculite used was of super fine texture. The water content of the substrates was maintained close to the soil field capacity with daily irrigations.

The number of emerged seedlings was recorded daily, and the final emergence percentage was determined after the $18^{\text {th }}$ day. The emergence rate index (ERI, seedling day ${ }^{-1}$ ) was calculated using Maguire's equation (Maguire, 1962): ERI $=\Sigma\left(n_{\mathrm{i}} / t_{\mathrm{i}}\right)$, where $n_{\mathrm{i}}$ is the number of emerged seedlings on a given day, and $t$ is the time in days from the sowing day (0). The mean emergence time (MET, in day) was calculated using the equation of Labouriau (1983): $\mathrm{MET}=\left(\sum n_{\mathrm{i}} t_{\mathrm{i}}\right) / \Sigma n_{\mathrm{i}}$, where $n_{\mathrm{i}}$ is the number of emerged seedlings on a given day, and $t_{\mathrm{i}}$ is the time in days from the sowing day (0). The mean emergence rate (MER, in day ${ }^{-1}$ ) was calculated using the equation of Labouriau (1983): MER $=1 /$ MET, where MET is mean emergence time.

At 65 days after sowing (DAS), the plant height, root collar diameter, and dry matter partitioning into shoots and roots were measured. Plant height $(\mathrm{PH})$, in centimeters, was determined from the substrate level of the container to the apical meristem with the assistance of a millimeter ruler. Root collar diameter (CD), in millimeters, was measured using a digital caliper (Park Tool DC1 - 150mm), with an accuracy of $\pm 0.01 \mathrm{~mm}$. For the determination of shoot (SDM) and root dry matter (RDM), the seedlings were separated into shoots and roots, dried in oven at $65^{\circ} \mathrm{C}$ for three days, and then weighed. From these measurements were calculated total dry matter (TDM), shoot: root dry matter ratio [SRR; shoot dry matter (g)/root dry matter (g)], height: diameter ratio [HDR; plant height $(\mathrm{cm}) /$ collar diameter $(\mathrm{mm})$ ], height: shoot dry matter ratio [HSR; plant height $(\mathrm{cm}) /$ shoot dry matter $(\mathrm{g})]$, and Dickson quality index [DQI = TDM/(SRR + HDR] (Dickson et al., 1960).

The data were subjected to analysis of variance (F-test, $\mathrm{p}=0.05$ ), and the means of two production environments and substrate types were compared by the F and Scott-Knott test, respectively, both at the 0.05 level of confidence. All analyses were performed using Sisvar 5.3 software for Windows ${ }^{\text {Tit }}$ (Ferreira, 2010).

\section{RESULTS AND DISCUSSION}

The ratio between the residual mean square (RMSr) for emergence rate index (ERI) and emergence percentage was lower than 7.0 (Table 1), therefore, allowing the comparison of the production environments by the joint analysis of both experiments (Banzatto \& Kronka, 2013).

The different protected environments and substrates used did not significantly effect $(p>0.05)$ the emergence of jatoba seedlings (Table 1). The emergence 
Table 1. Effects of different production environments and substrate composition on the emergence rate index (ERI) and emergence percentage of jatoba seedlings [Hymenaea courbaril L. var. stilbocarpa (Hayne)] Lee et Lang.]. Cassilândia-MS, 2012-2013.

\begin{tabular}{|c|c|c|c|c|}
\hline \multirow[b]{2}{*}{ Substrates } & \multicolumn{2}{|c|}{ Emergence percentage } & \multicolumn{2}{|c|}{ Emergence rate index } \\
\hline & $\begin{array}{c}\text { Black shading } \\
\text { screen }\end{array}$ & $\begin{array}{c}\text { Aluminized } \\
\text { screen }\end{array}$ & $\begin{array}{l}\text { Black shading } \\
\text { screen }\end{array}$ & $\begin{array}{c}\text { Aluminized } \\
\text { screen }\end{array}$ \\
\hline $\mathrm{S} 1=100 \% \mathrm{M}$ & $91.7 \mathrm{Aa}$ & $95.0 \mathrm{Aa}$ & $1.41 \mathrm{Cb}$ & $2.24 \mathrm{Ca}$ \\
\hline $\mathrm{S} 2=90 \% \mathrm{M}+10 \% \mathrm{~V}$ & $96.7 \mathrm{Aa}$ & $96.7 \mathrm{Aa}$ & $1.53 \mathrm{Ca}$ & $1.18 \mathrm{Da}$ \\
\hline $\mathrm{S} 3=80 \% \mathrm{M}+20 \% \mathrm{~V}$ & $98.3 \mathrm{Aa}$ & $98.3 \mathrm{Aa}$ & $2.14 \mathrm{Ba}$ & $1.17 \mathrm{Db}$ \\
\hline$S 4=70 \% M+30 \% V$ & $96.7 \mathrm{Aa}$ & $98.3 \mathrm{Aa}$ & $2.72 \mathrm{Aa}$ & $1.87 \mathrm{Cb}$ \\
\hline $\mathrm{S} 5=60 \% \mathrm{M}+40 \% \mathrm{~V}$ & $96.7 \mathrm{Aa}$ & $96.7 \mathrm{Aa}$ & $2.58 \mathrm{Aa}$ & $2.65 \mathrm{Ba}$ \\
\hline$S 6=50 \% M+50 \% V$ & $95.0 \mathrm{Aa}$ & $96.7 \mathrm{Aa}$ & $1.59 \mathrm{Cb}$ & $2.09 \mathrm{Ca}$ \\
\hline $\mathrm{S} 7=40 \% \mathrm{M}+60 \% \mathrm{~V}$ & $96.7 \mathrm{Aa}$ & $100.0 \mathrm{Aa}$ & $1.72 \mathrm{Cb}$ & $3.64 \mathrm{Aa}$ \\
\hline $\mathrm{S} 8=30 \% \mathrm{M}+70 \% \mathrm{~V}$ & $98.3 \mathrm{Aa}$ & $96.7 \mathrm{Aa}$ & $1.34 \mathrm{Cb}$ & $2.89 \mathrm{Ba}$ \\
\hline S9 $=20 \% \mathrm{M}+80 \% \mathrm{~V}$ & $98.3 \mathrm{Aa}$ & $93.3 \mathrm{Aa}$ & $1.53 \mathrm{Ca}$ & $1.75 \mathrm{Ca}$ \\
\hline $\mathrm{S} 10=10 \% \mathrm{M}+90 \% \mathrm{~V}$ & $98.3 \mathrm{Aa}$ & $93.3 \mathrm{Aa}$ & $1.45 \mathrm{Cb}$ & $3.22 \mathrm{Aa}$ \\
\hline CV (\%) & \multicolumn{2}{|c|}{5.82} & \multicolumn{2}{|c|}{17.37} \\
\hline $\mathrm{RMSr}$ & \multicolumn{2}{|c|}{1.12} & \multicolumn{2}{|c|}{1.97} \\
\hline Fc (Environments - E) & \multicolumn{2}{|c|}{$0.02^{\text {ns }}$} & \multicolumn{2}{|c|}{$44.21^{\star \star}$} \\
\hline Fc (Substrates - S) & \multicolumn{2}{|c|}{$0.71^{\mathrm{ns}}$} & \multicolumn{2}{|c|}{$15.61^{\star \star}$} \\
\hline $\mathrm{Fc}(\mathrm{E} \times \mathrm{S}$ interaction $)$ & \multicolumn{2}{|c|}{$0.71^{\mathrm{ns}}$} & \multicolumn{2}{|c|}{$21.68^{\star *}$} \\
\hline
\end{tabular}

Mean values followed by the same upper-case letters, in columns between production environments, or same lower-case letters, in the rows for the substrates, in each variable, are not significantly different by Scott-Knott and F test, respectively, both at the $5 \%$ probability level. $\mathrm{M}$ = cattle manure; $\mathrm{V}$ = vermiculite. $\mathrm{CV}$ = coefficient of variation; RMSr: ratio between the residual mean square of individual analyses of both production environments. Fc $=\mathrm{F}$ value calculated; ${ }^{* *}$ significant at $1 \%$ probability; ${ }^{\text {ns }}$ not significant.

of seedlings started nine days after sowing and high emergence percentage was observed in all environments and substrates tested (ranging from 91.7 to $100 \%$ ). This high emergence rate was higher than the results reported by Pierezan et al. (2012), who verified that the emergence percentage at 14 days ranged from 58 to $79 \%$. Carvalho et al. (2003) also verified a lower emergence percentage of jatoba seedlings, reporting that at 20 days after sowing only $26 \%$ and $41 \%$ of jatoba seedlings emerged when they were kept in protected environment with $50 \%$ shading screen and under full sun conditions, respectively. The high emergence percentage values obtained in this study indicates that the jatoba seeds used were of high physiological quality and vigor.

The ERI of jatoba seedlings was significantly affected $(\mathrm{p}<0.05)$ by the different protected environments and substrates (Table 1). In the environment with black shading screen, the substrates containing $60 \%$ and $70 \%$ of cattle manure resulted in the highest ERI values, whereas in the environment with thermal-reflective aluminized screen the substrates containing $40 \%$ and $10 \%$ of cattle manure resulted in the highest ERI. In general, the environment with thermal-reflective aluminized screen provided the highest ERI values compared to the environment with black shading screen. Equivalent results were reported by Santos et al. (2011), who also found higher ERI when the Hymenaea stigonocarpa seedlings were grown in the environment with thermal-reflective aluminized screen. These results indicate that the environment with thermal-reflective aluminized screen improved the ERI because it provided the best microclimatic conditions for the emergence of jatoba seedlings. In high light intensity conditions, as in the summer, the use of thermo-reflective aluminized screen reduces the input of the infrared radiation (heat) into the protected environment, reducing the internal temperature of the screenhouse compared to the external environment (Costa et al., 2016), thus avoiding the excess temperature that can heat the substrate.

The different protected environments and substrates significantly affected $(\mathrm{p}<0.05)$ the mean emergence time (MET) and mean emergence rate (MER) of jatoba seedlings (Table 2). In the environment with black shading screen, the MET ranged from 13.5 to 14.6 days, and was significantly greater when seeds were sown in the substrates containing the lowest proportions of cattle manure (i.e., $10 \%, 20 \%$ and $30 \%$ of manure), and lower 
Table 2. Effects of different production environments and substrate composition on the mean emergence time (MET) and mean emergence rate (MER) of jatoba seedlings [Hymenaea courbaril L. var. stilbocarpa (Hayne)] Lee et Lang.]. Cassilândia-MS, 2012-2013.

\begin{tabular}{|c|c|c|c|c|}
\hline \multirow[b]{2}{*}{ Substrates } & \multicolumn{2}{|c|}{ Mean emergence time } & \multicolumn{2}{|c|}{ Emergence mean rate } \\
\hline & $\begin{array}{c}\text { Black shading } \\
\text { screen }\end{array}$ & $\begin{array}{c}\text { Aluminized } \\
\text { screen }\end{array}$ & $\begin{array}{c}\text { Black shading } \\
\text { screen }\end{array}$ & $\begin{array}{c}\text { Aluminized } \\
\text { screen }\end{array}$ \\
\hline $\mathrm{S} 1=100 \% \mathrm{M}$ & $13.9 \mathrm{Ba}$ & $13.6 \mathrm{Ba}$ & $0.0721 \mathrm{Ba}$ & $0.0735 \mathrm{Ba}$ \\
\hline $\mathrm{S} 2=90 \% \mathrm{M}+10 \% \mathrm{~V}$ & $14.0 \mathrm{Ba}$ & $14.3 \mathrm{Aa}$ & $0.0713 \mathrm{Ba}$ & $0.0700 \mathrm{Da}$ \\
\hline $\mathrm{S} 3=80 \% \mathrm{M}+20 \% \mathrm{~V}$ & $13.9 \mathrm{Bb}$ & $14.3 \mathrm{Aa}$ & $0.0722 \mathrm{Ba}$ & $0.0698 \mathrm{Db}$ \\
\hline $\mathrm{S} 4=70 \% \mathrm{M}+30 \% \mathrm{~V}$ & $13.5 \mathrm{Cb}$ & $13.8 \mathrm{Ba}$ & $0.0739 \mathrm{Aa}$ & $0.0723 \mathrm{Cb}$ \\
\hline $\mathrm{S} 5=60 \% \mathrm{M}+40 \% \mathrm{~V}$ & $13.6 \mathrm{Ca}$ & $13.6 \mathrm{Bb}$ & $0.0733 \mathrm{Aa}$ & $0.0740 \mathrm{Ba}$ \\
\hline$S 6=50 \% M+50 \% V$ & $14.1 \mathrm{Ba}$ & $13.5 \mathrm{Ca}$ & $0.0704 \mathrm{Cb}$ & $0.0733 \mathrm{Ba}$ \\
\hline $\mathrm{S} 7=40 \% \mathrm{M}+60 \% \mathrm{~V}$ & $14.1 \mathrm{Ba}$ & $13.3 \mathrm{Cb}$ & $0.0712 \mathrm{Bb}$ & $0.0750 \mathrm{Aa}$ \\
\hline $\mathrm{S} 8=30 \% \mathrm{M}+70 \% \mathrm{~V}$ & $14.6 \mathrm{Aa}$ & $13.4 \mathrm{Cb}$ & $0.0688 \mathrm{Cb}$ & $0.0748 \mathrm{Aa}$ \\
\hline S9 $=20 \% M+80 \% V$ & $14.4 \mathrm{Aa}$ & 14.1 Aa & $0.0695 \mathrm{Ca}$ & $0.0708 \mathrm{Da}$ \\
\hline $\mathrm{S} 10=10 \% \mathrm{M}+90 \% \mathrm{~V}$ & $14.5 \mathrm{Aa}$ & $13.3 \mathrm{Cb}$ & $0.0691 \mathrm{Cb}$ & $0.0753 \mathrm{Aa}$ \\
\hline CV (\%) & \multicolumn{2}{|c|}{1.68} & \multicolumn{2}{|c|}{1.63} \\
\hline $\mathrm{RMSr}$ & \multicolumn{2}{|c|}{1.48} & \multicolumn{2}{|c|}{2.00} \\
\hline Fc (Environments - E) & \multicolumn{2}{|c|}{$48.45^{* *}$} & \multicolumn{2}{|c|}{$52.32^{* *}$} \\
\hline Fc (Substrates - S) & \multicolumn{2}{|c|}{$9.41^{* *}$} & \multicolumn{2}{|c|}{$9.65^{* *}$} \\
\hline $\mathrm{Fc}(\mathrm{E} \times \mathrm{S}$ interaction $)$ & \multicolumn{2}{|c|}{$16.06^{* *}$} & \multicolumn{2}{|c|}{$16.82^{\star *}$} \\
\hline
\end{tabular}

Mean values followed by the same upper-case letters, in columns between production environments, or same lower-case letters, in the rows for the substrates, in each variable, are not significantly different by Scott-Knott and F test, respectively, both at the 5\% probability level. $\mathrm{M}$ = cattle manure; $\mathrm{V}$ = vermiculite. $\mathrm{CV}=$ coefficient of variation; RMSr: ratio between the residual mean square of individual analyses of both production environments. Fc $=\mathrm{F}$ value calculated; ${ }^{* *}$ significant at $1 \%$ probability; ${ }^{\text {ns }}$ not significant.

with sowing in substrate containing $60 \%$ and $70 \%$ cattle manure. For the environment with thermo-reflective aluminized screen, the substrates containing 20\%, 80\% and $90 \%$ of cattle manure resulted in the highest MET of seedlings, whereas the shortest MET were observed in the substrates containing $10 \%, 30 \%, 40 \%$ and $50 \%$ of manure. These results indicate that the substrates containing $60 \%$ and $70 \%$ of cattle manure were the most suitable for the emergence process of seedlings in the environment with black shading screen, while in the environment with thermal-reflective aluminized screen, the substrates containing 10\%, 30\%, 40\%, and $50 \%$ were most appropriate for reducing MET and increase the EMR, consequently. A delay in the mean time to seedling emergence may be disadvantageous for successful establishment, since the delayed emergence leaves the seeds more vulnerable to attack from predators (pests and pathogens) and, therefore, compromise the establishment of a uniform stand.

The different production environments did not significantly affect $(\mathrm{p}>0.05)$ growth and quality indexes of jatoba seedlings (Table 3 ). The highest total dry matter yield of the seedlings was obtained using the substrate containing $10 \%, 20 \%$ and $30 \%$ of cattle manure. The highest root dry matter accumulation was obtained with the use of the substrates containing $10 \%$ and $20 \%$ of cattle manure. In general, these results report that the substrates with the variation of cattle manure from $10 \%$ to $50 \%$ were the most appropriate to produce jatoba seedlings, for improving the growth and quality index of the seedlings. The seedlings grown on these substrates did not present the highest plant height, however presented the best dry matter partitioning into shoot and roots, as well as the higher Dickson's quality index. Similarly, Carvalho et al. (2003) reported that the substrate containing a mixture of $25 \%$ soil, $50 \%$ sand and $25 \%$ cattle manure resulted in high quality jatoba seedlings.

More vigorous seedlings were obtained with the use of substrates with lower amounts of cattle manure, confirming the results reported by Santos et al. (2011), which also obtained better quality Hymenaea stigonocarpa seedlings with the use of substrates with lower rates of cattle manure. Costa et al. (2011) don't recommend the use of substrates containing only composted manure for the formation of $H$. stigonocarpa seedlings. According to Santos et al. (2011) the jatoba-do-cerrado (Hymenaea stigonocarpa) is a plant adapted to low fertility soils, 
Table 3. Effects of different substrate compositions on plant height (PH), root collar diameter (CD), root dry matter (RDM), total dry matter (TDM), shoot: root dry matter ratio (SRR), plant height: shoot dry matter ratio (HSR), height: diameter ratio (HDR), and Dickson's quality index (DQI) of jatoba seedlings [Hymenaea courbaril L. var. stilbocarpa (Hayne)] Lee et Lang.]. Cassilândia-MS, 2012-2013.

\begin{tabular}{|c|c|c|c|c|}
\hline Substrates & PH & CD & RDM & TDM \\
\hline $\mathrm{S} 1=100 \% \mathrm{M}$ & $47.3 \mathrm{~A}$ & $4.63 \mathrm{~B}$ & $0.789 \mathrm{C}$ & $4.19 \mathrm{~B}$ \\
\hline $\mathrm{S} 2=90 \% \mathrm{M}+10 \% \mathrm{~V}$ & $46.7 \mathrm{~A}$ & $4.76 \mathrm{~B}$ & $0.716 \mathrm{C}$ & $4.18 \mathrm{~B}$ \\
\hline$S 3=80 \% M+20 \% V$ & $48.3 \mathrm{~A}$ & $4.81 \mathrm{~B}$ & $0.793 \mathrm{C}$ & $4.39 \mathrm{~B}$ \\
\hline$S 4=70 \% M+30 \% V$ & $48.1 \mathrm{~A}$ & $4.96 \mathrm{~A}$ & $0.773 \mathrm{C}$ & $4.37 \mathrm{~B}$ \\
\hline $\mathrm{S} 5=60 \% \mathrm{M}+40 \% \mathrm{~V}$ & $47.8 \mathrm{~A}$ & $4.78 \mathrm{~B}$ & $0.847 \mathrm{C}$ & $4.38 \mathrm{~B}$ \\
\hline$S 6=50 \% M+50 \% V$ & $47.5 \mathrm{~A}$ & $4.77 \mathrm{~B}$ & $0.935 \mathrm{~B}$ & $4.72 \mathrm{~A}$ \\
\hline$S 7=40 \% M+60 \% V$ & $46.1 \mathrm{~A}$ & $4.84 \mathrm{~B}$ & $0.966 \mathrm{~B}$ & $4.47 \mathrm{~B}$ \\
\hline$S 8=30 \% M+70 \% V$ & $44.8 \mathrm{~B}$ & $5.07 \mathrm{~A}$ & $1.025 \mathrm{~B}$ & $4.63 \mathrm{~A}$ \\
\hline S9=20\%M +80\%V & $44.4 \mathrm{~B}$ & $4.90 \mathrm{~A}$ & $1.058 \mathrm{~A}$ & $4.58 \mathrm{~A}$ \\
\hline $\mathrm{S} 10=10 \% \mathrm{M}+90 \% \mathrm{~V}$ & $43.9 \mathrm{~B}$ & $4.83 \mathrm{~B}$ & $1.141 \mathrm{~A}$ & $4.76 \mathrm{~A}$ \\
\hline CV (\%) & 4.92 & 4.07 & 14.73 & 9.13 \\
\hline RMSr & 1.01 & 1.86 & 1.41 & 1.56 \\
\hline Fc (Environments - E) & $5.24^{*}$ & $4.32^{*}$ & $0.10^{\mathrm{ns}}$ & $1.96^{\mathrm{ns}}$ \\
\hline Fc (Substrates - S) & $4.93^{* *}$ & $3.64^{* *}$ & $11.30^{* *}$ & $2.48^{\star}$ \\
\hline $\mathrm{Fc}(\mathrm{E} \times \mathrm{S}$ interaction $)$ & $0.13^{\mathrm{ns}}$ & $0.23^{\text {ns }}$ & $0.38^{\mathrm{ns}}$ & $0.59^{\text {ns }}$ \\
\hline Substrates & SRR & HSR & HDR & DQI \\
\hline $\mathrm{S} 1=100 \% \mathrm{M}$ & $4.34 \mathrm{~B}$ & $13.99 \mathrm{~A}$ & $10.21 \mathrm{~A}$ & $0.288 \mathrm{~B}$ \\
\hline $\mathrm{S} 2=90 \% \mathrm{M}+10 \% \mathrm{~V}$ & $4.90 \mathrm{~A}$ & $13.64 \mathrm{~A}$ & $9.84 \mathrm{~A}$ & $0.284 \mathrm{~B}$ \\
\hline$S 3=80 \% M+20 \% V$ & $4.56 \mathrm{~A}$ & $13.46 \mathrm{~A}$ & $10.03 \mathrm{~A}$ & $0.302 \mathrm{~B}$ \\
\hline $\mathrm{S} 4=70 \% \mathrm{M}+30 \% \mathrm{~V}$ & $4.73 \mathrm{~A}$ & $13.41 \mathrm{~A}$ & $9.70 \mathrm{~A}$ & $0.304 \mathrm{~B}$ \\
\hline $\mathrm{S} 5=60 \% \mathrm{M}+40 \% \mathrm{~V}$ & $4.24 \mathrm{~B}$ & $13.55 \mathrm{~A}$ & $10.02 \mathrm{~A}$ & $0.309 \mathrm{~B}$ \\
\hline$S 6=50 \% M+50 \% V$ & $4.16 \mathrm{~B}$ & $12.63 \mathrm{~B}$ & $9.98 \mathrm{~A}$ & $0.336 \mathrm{~A}$ \\
\hline$S 7=40 \% M+60 \% V$ & $3.66 \mathrm{C}$ & $13.23 \mathrm{~A}$ & $9.52 \mathrm{~A}$ & $0.339 \mathrm{~A}$ \\
\hline$S 8=30 \% M+70 \% V$ & $3.56 \mathrm{C}$ & $12.44 \mathrm{~B}$ & $8.87 \mathrm{~B}$ & $0.374 \mathrm{~A}$ \\
\hline S9=20\%M +80\%V & $3.36 \mathrm{C}$ & $12.67 \mathrm{~B}$ & $9.06 \mathrm{~B}$ & $0.370 \mathrm{~A}$ \\
\hline$S 10=10 \% M+90 \% V$ & $3.20 \mathrm{C}$ & $12.16 \mathrm{~B}$ & $9.09 \mathrm{~B}$ & $0.388 \mathrm{~A}$ \\
\hline CV (\%) & 12.56 & 7.35 & 5.71 & 10.85 \\
\hline RMSr & 2.16 & 1.12 & 1.21 & 1.44 \\
\hline Fc (Environments - E) & $3.21^{\mathrm{ns}}$ & $0.43^{\text {ns }}$ & $0.23^{\text {ns }}$ & $0.06^{\mathrm{ns}}$ \\
\hline Fc (Substrates - S) & $13.49^{* *}$ & $3.89^{\star *}$ & $7.44^{\star *}$ & $11.17^{\star *}$ \\
\hline $\mathrm{Fc}(\mathrm{E} \times \mathrm{S}$ interaction $)$ & $0.35^{\mathrm{ns}}$ & $0.36^{\mathrm{ns}}$ & $1.87^{\mathrm{ns}}$ & $0.44^{\mathrm{ns}}$ \\
\hline
\end{tabular}

Mean values followed by the same upper-case letters, in the columns for the substrates, in each variable, are not significantly different by Scott-Knott test at the 5\% probability level; Parameter do not differ by Scott-Knott test at 5\% probability. $\mathrm{M}=$ cattle manure; $\mathrm{V}=$ vermiculite. $\mathrm{CV}=$ coefficient of variation; RMSr: ratio between the residual mean square of individual analyses of both production environments. $\mathrm{Fc}=\mathrm{F}$ value calculated; ${ }^{*}$ significant at $5 \%$ probability; ${ }^{* *}$ significant at $1 \%$ probability; ${ }^{\text {ns }}$ not significant.

such as Cerrado, and does not require large nutrition amounts for its initial growth and development. Duboc et al. (1996) reported that Hymenaea courbaril is a species with low nutritional requirements for $\mathrm{N}$, $\mathrm{P}, \mathrm{Ca}, \mathrm{Mg}, \mathrm{S}$, and $\mathrm{K}$, and that excess of B and $\mathrm{Zn}$ may cause phytotoxicity effects on seedlings.

The DQI of jatoba seedlings ranged from 0.284 to 0.388 (Table 3 ), and was higher than the values observed by Pierezan et al. (2012), which verified DQI ranging from 0.072 to 0.109 for jatoba seedlings grown in Dourados-MS. The DQI is considered a promising integrated measure of morphological traits and thought to be a good indicator of seedling quality as its calculation computes robustness and dry matter distribution while considering several important parameters, such as height, diameter, and dry matter (Fonseca et al., 2002). The highest DQI values indicates that the seedlings are more vigorous and present a higher survival rate when transplanted in the field.

The HDR of jatoba seedlings ranged from 8.87 to 10.21 (Table 3 ) and was lower than the values 
obtained by Pierezan et al. (2012), where values ranged from 14.46 to 19.20. In general, studies on seedling production in protected environments indicate that a high-quality seedling should have a value of HDR ranging from 4.0 to 6.0, and a HDR higher than 8.0 can be indicative of seedling etiolating. The higher quality of the jatoba seedlings obtained in this study in comparison to the seedlings produced in Dourados-MS by Pierezan et al. (2012), indicates that the substrates used in this study were more adequate to the growth of the seedlings.

The plant height of the jatoba seedlings at 65 days after sowing (DAS) ranged from 43.9 to $48.3 \mathrm{~cm}$ (Table 3) and was higher than the values observed by Sano \& Fonseca (2003) and Campos \& Uchida (2002) that obtained height of the Hymenaea spp. seedlings of 33.0 and $36.4 \mathrm{~cm}$ at 270 and 150 DAS, respectively. Carvalho et al. (2003) cultivating jatoba seedlings in environment with $50 \%$ black shading screen obtained plant height of $34.31 \mathrm{~cm}$ at 180 DAS. Lima et al. (2010) obtained seedlings with $54.2 \mathrm{~cm}$ of height at 120 DAS in a 50\% shading screenhouse. Pierezan et al. (2012) verified plant height of $11.4 \mathrm{~cm}$ and $25.75 \mathrm{~cm}$ at 40 and 226 DAS, respectively, in a $50 \%$ shading screenhouse. The highest height of the jatoba seedlings obtained in this study indicates that the plants showed an excellent growth performance and that the species has a good adaptation to the climatic conditions of Cassilândia-MS when grown in protected environments.

The different protected environments significantly affected $(\mathrm{p}<0.05)$ the plant height $(\mathrm{PH})$ and root collar diameter (CD) of jatoba seedlings (Table 4). The cultivation of the seedlings in environment with black shading screen resulted in greater plant height and collar diameter compared to the environment with thermal-reflective aluminized screen. Lima et al.

Table 4. Effects of production environments on the plant height $(\mathrm{PH})$ and root collar diameter (CD) of the jatoba seedlings [Hymenaea courbaril L. var. stilbocarpa (Hayne)] Lee et Lang.]. Cassilândia-MS, 2012-2013.

\section{Production environments}

Black shading screen PH $47.00 \mathrm{~A} \quad 4.88 \mathrm{~A}$ Thermal-reflective aluminized screen $\quad 45.96 \mathrm{~B} \quad 4.79 \mathrm{~B}$

Mean values followed by the same upper-case letters, in the columns between production environments, in each variable are not significantly different by $\mathrm{F}$ test at the $5 \%$ probability level.
(2010) verified that the lower height seedlings were obtained under full sun conditions, while the highest plant height was observed in a 50\% shading screenhouse compared to the environments with $30 \%$ and $80 \%$ shading screens. The $\mathrm{CD}$ of the jatoba seedlings at 65 DAS was approximately $4.84 \mathrm{~mm}$, this value is similar $(5.0 \mathrm{~mm})$ to those reported by Carvalho et al. (2003) at 180 DAS, and higher $(2.70 \mathrm{~mm})$ than the values reported by Pierezan et al. (2012) at 226 DAS.

\section{CONCLUSIONS}

The use of substrate containing the highest proportions of cattle manure ( $60 \%$ and $70 \%$ ) in combination with vermiculite (v:v) improved the emergence velocity rates of jatoba seedlings when grown in a black shading screenhouse.

The highest emergence velocity rates of the jatoba seedlings in the environment with thermo-reflective aluminized screen were obtained using substrates with the lowest proportions of cattle manure (10\% and $40 \%)$ in combination with vermiculite (v:v).

The environment protected with black shading screen was more favorable for the formation of jatoba seedlings, resulting in seedlings with higher shoot height and root collar diameter and, therefore, higher quality.

It is recommended to use substrates containing up to $30 \%$ of cattle manure in the substrate volume to produce high quality jatoba seedlings.

\section{ACKNOWLEDGEMENTS}

The authors acknowledge the Foundation for Support to the Development of Education, Science and Technology of the State of Mato Grosso do Sul - FUNDECT (FUNDECT/CNPq/PRONEM 15/2014; FUNDECT/ PAPOS 025/2015; FUNDECT/CNPq/PPP 05/2011) and Coordination for the Improvement of Higher Education Personnel (CAPES/PAPOS) for financial support and granting of scholarships.

\section{SUBMISSION STATUS}

Received: 4 sep., 2015

Accepted: 9 july, 2018 


\section{CORRESPONDENCE TO}

\section{Edilson Costa}

Unidade Universitária de Cassilândia, Universidade Estadual de Mato Grosso do Sul - UEMS, Rodovia MS 306, Km 6,5, CEP 79540-000, Cassilândia, MS, Brasil e-mail: mestrine@uems.br

\section{FINANCIAL SUPPORT}

CAPES, (Grant/Award Number: 'CAPES/PAPOS'). Conselho Nacional de Desenvolvimento Científico e Tecnológico, (Grant/Award Number: 'Bolsa'). Fundação de Apoio ao Desenvolvimento do Ensino, Ciência e Tecnologia do Estado de Mato Grosso do Sul, (Grant/Award Number: 'FUNDECT (FUNDECT/CNPq/PRONEM 15/2014; FUNDECT/PAPO').

\section{REFERENCES}

Aidar MPM, Martinez CA, Costa AC, Costa PMF, Dietrich SMC, Buckeridge MS. Effect of atmospheric $\mathrm{CO}_{2}$ enrichment on the establishment of seedlings of Jatobá, Hymenaea Courbaril L. (Leguminosae, Caesalpinioideae). Biota Neotropica 2002; 2(1): 1-10. http://dx.doi.org/10.1590/ S1676-06032002000100008.

Banzatto DA, Kronka SN. Experimentação agrícola. 4th ed. Jaboticabal: FUNEP; 2013.

Campos MA, Uchida T. Influência do sombreamento no crescimento de mudas de três espécies amazônicas. Pesquisa Agropecuária Brasileira 2002; 37(3): 281-288. http://dx.doi.org/10.1590/S0100-204X2002000300008.

Carvalho JLS Fo, Arrigoni-Blank MF, Blank AF, Rangel MAS. Produção de mudas de jatobá (Hymenaea courbaril L.) em diferentes ambientes, recipientes e composições de substratos. Cerne 2003; 9(1): 109-118.

Costa E, Leal PAM, Rego NH, Benatti J. Desenvolvimento inicial de mudas de jatobazeiro do cerrado em AquidauanaMS. Revista Brasileira de Fruticultura 2011; 33(1): 215-226. http://dx.doi.org/10.1590/S0100-29452011005000035.

Costa VM, Folegatti MV, Atarassi RT, Duarte SN, Dias NDS, Silva CR. Desenvolvimento de mudas de cafeeiro produzidas em tubetes sob malhas termo-refletoras e malha negra. Irriga 2016; 1(1): 52-65. http://dx.doi. org/10.15809/irriga.2016v1n1p52-65.

Dickson A, Leaf AL, Hosner JF. Quality appraisal of white spruce and white pine seedling stock in nurseries. Forestry Chronicle 1960; 36(1): 10-13. http://dx.doi.org/10.5558/ tfc36010-1.
Duboc E, Venturin N, Vale FR, Davide AC. Nutrição do jatobá (Hymenae courbaril L. var. Stilbocarba (Haene) Lee et lang). Cerne 1996; 2(1): 138-152.

Ferreira DF. Sisvar - Sistema de análise de variância. Versão 5.3. Lavras: UFLA; 2010.

Fonseca ÉP, Valéri SV, Miglioranza É, Fonseca NAN, Couto L. Padrão de qualidade de mudas de Trema micrantha (L.) Blume, produzidas sob diferentes períodos de sombreamento. Revista Árvore 2002; 26(4): 515-523. http://dx.doi.org/10.1590/S0100-67622002000400015.

Gandini AMM, Santos JB, Andrezza MMG, Santana RC, Cunha VC, Silva, DV, Fiore RA. Capacidade competitiva do jatobá com adubos verdes, forrageiras e plantas daninhas. Planta Daninha 2011;29(N. esp): 991-999. https://dx.doi. org/10.1590/S0100-83582011000500005. <jrn>

Labouriau LG. A germinação das sementes. Washington: Secretaria Geral da Organização dos Estados Americanos; 1983. (Série de Biologia. Monografia; no. 24).

Lima ALS, Zanella F, Castro LDM. Crescimento de Hymenaea courbaril L. var. stilbocarpa (Hayne) Lee et Lang. e Enterolobium contortisiliquum (Vell.) Morong (Leguminosae) sob diferentes níveis de sombreamento. Acta Amazonica 2010; 40(1): 43-48. http://dx.doi.org/10.1590/ S0044-59672010000100006.

Lorenzi H. Arvóres brasileiras: manual de identificação e cultivo de plantas arbóreas nativas do Brasil. $3 \mathrm{rd}$ ed. Nova Odessa: Instituto Plantarum; 2000. 352 p.

Maguire JD. Speed of germination - aid in selection and evaluation for seedling emergence and vigor. Crop Science 1962; 2(1): 176-177. http://dx.doi.org/10.2135/cropsci19 62.0011183X000200020033x

Mazzei LJ, Sousa-Silva JC, Felfili JM, Rezende AV, Franco AC. Crescimento de plantulas de Hymenaea courbaril L. var. stilbocarpa (Hayne) Lee \& Lang. em viveiro. Boletim do Herbario Ezechias Paulo Heringer 1999; 4(1): 21-29.

Oliveira WL, Medeiros MB, Moser P, Pinheiro R, Olsen LB. Regeneração e estrutura populacional de jatobá-damata (Hymenaea courbaril L.), em dois fragmentos com diferentes graus de perturbação antrópica. Acta Botanica Brasilica 2011; 25(4): 876-884. http://dx.doi.org/10.1590/ S0102-33062011000400014.

Pierezan L, Scalon SPQ, Pereira ZV. Emergência de plântulas e crescimento de mudas de jatobá com uso de bioestimulante e sombreamento. Cerne 2012; 18(1): 127 133. http://dx.doi.org/10.1590/S0104-77602012000100015.

Sano SM, Fonseca CEL. Estabelecimento de progênies de jatobá (Hymenaea spp) em plantios puros no Cerrado. Planaltina: Embrapa Cerrados; 2003. 14 p. (Boletim de Pesquisa e Desenvolvimento; no. 110).

Santos LCR, Costa E, Leal PAM, Nardelli EMV, Souza GSA. Ambientes protegidos e substratos com doses de composto orgânico comercial e solo na formação de mudas de Jatobazeiro em Aquidauana-MS. Engenharia Agrícola 2011; 31(2): 249-259. http://dx.doi.org/10.1590/ S0100-69162011000200005. 